\title{
Article \\ The Impact of Intellectual Capital on the Profitability of Russian Agricultural Firms
}

\author{
Danila V. Ovechkin*(D, Gulnara F. Romashkina (D) and Vladimir A. Davydenko
}

check for updates

Citation: Ovechkin, D.V.;

Romashkina, G.F.; Davydenko, V.A. The Impact of Intellectual Capital on the Profitability of Russian Agricultural Firms. Agronomy 2021, 11, 286. https://doi.org/10.3390/ agronomy11020286

Academic Editor: Derek Baker Received: 14 January 2021

Accepted: 1 February 2021

Published: 4 February 2021

Publisher's Note: MDPI stays neutral with regard to jurisdictional claims in published maps and institutional affiliations.

Copyright: (c) 2021 by the authors. Licensee MDPI, Basel, Switzerland. This article is an open access article distributed under the terms and conditions of the Creative Commons Attribution (CC BY) license (https:/ / creativecommons.org/licenses/by/ $4.0 /)$.
Department of Economics and Finance, Tyumen State University, Tyumen 625003, Russia; gr136@mail.ru (G.F.R.); vlad_davidenko@mail.ru (V.A.D.)

* Correspondence: dv.ovechkin@mail.ru

\begin{abstract}
Economic efficiency is a function of two types of resources: those that are presented in financial statements and those that are not. Non-balance sheet resources are referred as to intellectual capital (IC). The purpose of the paper is to investigate the relationship between IC, its components and the level of financial profitability. To conduct the analysis, we used the system generalized method of moments for a broad sample of Russian firms that operate in the agribusiness industry. We employed two financial approaches to IC estimation. The first one is the Value Added Intellectual Coefficient (VAIC). The second one is own-created approach that is supposed to respond the criticism regarding VAIC. Comparison between VAIC and own-created approach to IC estimation revealed that the latter is more appropriate due to its advantages. Our approach unlike VAIC allows measuring both efficiency ratios and the stocks of IC. The results showed that the efficiency of structural capital usage and the stock of human capital have the biggest impact on the profitability level of the agricultural businesses among employed measures of IC.
\end{abstract}

Keywords: intellectual capital; agriculture; economics

\section{Introduction}

The increasing importance of intellectual capital (IC) as a strategic asset capable of generating a sustainable competitive advantage over time has led to the need for an acceptable measurement model, since traditional financial tools do not address the necessary intellectual capital concepts.

Intellectual capital consists of intangible assets that can be converted into profits (and value) but are not reflected on firm financial statements [1,2]. Researchers can highlight different elements of intellectual capital depending on the research goals. Commonly, studies classify intellectual capital into three components: human capital (skills, experience, and competencies of employees); structural capital (processes, methods, and brands owned by a company); and relational capital (relation network).

Intellectual capital positively affect firms' performance and encourages the process of value creation [3]. Intellectual capital is the source of sustainable development [4-6]. That is why many studies aim to investigate how intellectual capital and its value can be determined. Methods of intellectual capital estimation are varied [7-9]. Methods that allow estimating IC with financial reports are very appreciated because of objective and quantitative financial information. The most popular financial indicator of IC and its components is the value-added intellectual coefficient (VAIC); according to Pedro et al. [10]. VAIC shows the efficiency of the IC elements and allows cross-organizational and crossnational comparison.

Many studies are focused on modifying VAIC by extending the list of intellectual capital components rejected by the original VAIC approach [11-15]. However, we argue that all the VAIC's modifications still do not respond the criticism expressed by many authors [16-19]. Disadvantages of VAIC are various and the main one is that the intellectual capital stock assessment is impossible. When VAIC is applied, researchers can only calculate 
the set of efficiency ratios that are presumably related to the stock of intellectual capital. Other financial methods of IC estimation have the same disadvantage.

Thus, one of the objectives of this study is to propose the approach to intellectual capital estimation that allows evaluating the value of IC components and their efficiency separately. In addition, this study contributes to academic discourse about the economic development of agricultural firms by using the agribusiness industry as a research setting (agribusiness industry can be defined as a set of interconnected vertical markets with firms operating in the production, processing and marketing of agricultural products). As noted by Kozera-Kowalska [20], papers addressing the role to be played by intellectual capital in agricultural holding management have only started to emerge in recent years and there is a lack of studies related to intellectual capital and agribusiness. As noted by Scafarto et al. [21], agribusiness is heavily reliant on intellectual capital. This is not surprising, since intellectual capital encourages innovations that are pivotal to facing the increasing uncertainty of the operating environment and allowing economic survival through competitiveness [22]. This paper extends existing investigations by using the agribusiness industry as a research setting.

Russian agribusiness enterprises are taken into consideration in our study. Shakina et al. [23] state that there is a gap of competitiveness (or productivity) between Russian companies and their foreign competitors, and the reason for this gap is the lack of intangibles. The importance of IC for Russian firms determines the relevance of our study.

The remaining part of the paper proceeds as follows: next section presents a literature review about intellectual capital and its measurement. Section 3 introduces the authors approach to intellectual capital estimation. The research methodology is explained in Section 4 . Section 5 shows the empirical results and presents the conclusion.

\section{Background}

\subsection{Intellectual Capital Definition and Classification}

The World Intellectual Capital Initiative identifies intellectual capital as a range of external (brand, reputation etc.) and internal (skills, competencies, etc.) dynamically connected intangible assets which allows firms to transform tangible assets and financial and human resources into a system of value creation. Yound et al. [24] and Roose et al. [25] defined IC as the knowledge that can be used by an organization in order to achieve business goals and rise long-term competitiveness. IC is seen as the intangible assets that help a company to sustain its operations [26,27].

There are many classifications of intellectual capital elements. Commonly suggested IC components are the following: human capital, structural capital, and relational capital. Human capital can be defined as a combination of the following employees' characteristics: genetic inheritance, education, experience, and attitudes to life and business [28]. Bontis [1] emphasizes the importance of human capital because it brings innovations and strategic renewal.

Structural capital consists of organizational processes, trademarks, databases, information systems, cultural aspects, and other elements of the intellectual infrastructure of an organization $[29,30]$. Structural capital is what stays at the firm after its employees go home and consists of processes, methods, brands, intellectual property structures, and other hidden intangibles [31]. Structural capital is always divided into innovational capital and process capital [31]. Innovational capital represents willingness of a firm to extend innovations through R\&D (research and development) and process capital represents activities which are used to improve efficiency and raise the quality of business processes [21].

Relational capital represents all resources that can emerged from the relation network [32]. Relational capital is the ability of an organization to take knowledge that flow from interaction with the external community [1]. The external community consists of suppliers, customers, government, and so on. 


\subsection{Intellectual Capital Measurement}

Measuring intellectual capital's value is not an easy procedure because financial reports do not supply needed information about intangibles. Thus, researchers seek different approximations and develop various approaches to measuring intellectual capital. Goebel [7] categorizes these approaches into three groups, depending on the information sources used.

The first group represents component-based approaches. The essence of componentbased approaches is the estimation of single IC components. After IC components are determined, a researcher can measure the aggregate value of IC. Goebel [7] summarizes that this group of approaches is rarely used because there is a lack of available information regarding individual IC components. In addition, as noticed by Mouritsen [33], the unobservable interactions of IC components are hidden when component-based measures are applied. The interaction effect contributes considerably to the IC value [34].

The second group contains holistic market-based approaches. Holistic market-based approaches assume that IC and the interaction effects of the IC elements can be fully captured in the overall value. Penman [35] argued that IC increases earnings with an effect on company value. Thus, IC can be observed as the disparity between firms' market value and their book value. However, measures that are related to holistic market-based approaches do not allow estimating components of IC.

The third group consists of investment-based approaches that are based on financial statement information. All costs related to intellectual capital are considered as investments in intellectual capital when investment-based approaches are applied. As, for example, labor expenses can be considered human capital investments. Investment-based approaches allow estimating IC components based on objective financial information about cash flows related to each of the IC components.

Every method is appropriate for specific business, economic, and strategic goals. Our study investigates investment-based approaches. Goebel [7] emphasized VAIC as the most important model related to investment-based approaches. Pedro et al. [10] also noticed that the VAIC methodology is the most popular among researchers. Many studies emphasize the following advantages of using VAIC:

- $\quad$ VAIC can show the efficiency of the IC elements unlike other relevant IC financial metrics such as economic value added (EVA) [36].

- VAIC avoids using unavailable, subjective and qualitative information that cannot be translated into quantitative values [37].

- VAIC allows cross-organizational and cross-national comparison [13]. Firer and Williams [38] claimed that the other models of IC measurement are customized to fit a specific firm's profile, which limits comparability.

VAIC was introduced by Ante Pulic [36,39]. The original equation of VAIC contains efficiency ratios of intellectual capital and financial capital (or capital employed):

$$
\mathrm{VAIC}=\mathrm{ICE}+\mathrm{CEE}
$$

where ICE is the intellectual capital efficiency, and CEE is the capital employed efficiency.

According to the original VAIC model, intellectual capital contains only human capital and structural capital:

$$
\mathrm{ICE}=\mathrm{HCE}+\mathrm{SCE}
$$

where HCE is the human capital efficiency, and SCE is the structural capital efficiency.

Next, we will analyze in detail how these coefficients are calculated and what they consist of. But before, the concept of value added should be discussed. The value created by the firm, or value added (VA), is defined as the difference between output and input, where the output is the overall income from all of the products and services sold on the market and the input is all the expenses of everything that came into the company [39]. 
Labor expenses are not included in the input because they are considered as investments due to employees' active role in creation of VA. Thus, value added is defined as follows:

$$
\mathrm{VA}=\mathrm{OP}+\mathrm{HC}+\mathrm{D}+\mathrm{A}
$$

where VA is the value added, OP is the operating profit, $\mathrm{HC}$ represents employee costs, D stands for the depreciation and A stands for the amortization.

After VA is calculated, it is possible to measure the efficiency ratios (Equations (1) and (2)). CEE shows how efficiently financial capital is used when creating companies value. $C E$ (capital employed) is usually taken as the book value of net assets of the organization. CEE is defined as follows:

$$
\mathrm{CEE}=\frac{\mathrm{VA}}{\mathrm{CE}}
$$

where VA is the value added and CE is the capital employed.

HCE is the ratio of value added to the payments that are received by the employees such as salary, social security etc:

$$
\mathrm{HCE}=\frac{\mathrm{VA}}{\mathrm{HC}}
$$

where VA is the value added and $\mathrm{HC}$ represents total wages and salaries.

SCE is the ratio of VA to the part of VA that is referred to structural capital (or SC). Pulic [39] argues that the less human capital participates in value creation, the more structural capital is involved. Based on this revers relationship SC can be defined as the difference between value added and human capital:

$$
\mathrm{SC}=\mathrm{VA}-\mathrm{HC}=\mathrm{OP}+\mathrm{D}+\mathrm{A}
$$

SCE is calculated as follows:

$$
\mathrm{SCE}=\frac{\mathrm{SC}}{\mathrm{VA}}
$$

where SC is the difference between VA and HC or the sum of OP, D, and A (Equation (6)) and VA is the value added.

Despite its advantages, VAIC has been criticized in several aspects. Andriessen [16] states that he has some difficulties with the basic assumptions of VAIC:

(1) The VAIC method does not properly separate expenses from assets. Assets contribute to future benefits while expenses do not provide any benefits beyond the accounting period. Thus, labor costs (excluding training expenses and wages of $R \& D$ employees) should be recognized as expenses.

(2) The VAIC method confuses stocks and flows. Under the VAIC methodology, SCE and HCE do not represent the value of structural nor human capital.

(3) VAIC' ratios do not calculate efficiency. As an example, Andriessen [16] states that HCE does not provide information about the contribution of human capital to value creation.

(4) The assumption of the reverse relationship of human capital and structural capital leads to a result where HCE is bigger than SCE every time when VA is bigger than zero. Andriessen [16] claims that this result is dissatisfying and can lead to the wrong conclusion about human resource assets and structural assets effectiveness.

(5) VAIC ignores the synergies between intellectual capital components.

(6) Variables which are not related to intellectual capital can affect VAIC (for example, if capital employed is small to zero due to big liabilities and little net assets, CEE and VAIC will be very high).

\subsection{A literature Review of VAIC Modifications}

Many studies have attempted to improve the original VAIC model. Some IC components were not included in the original VAIC model. Chang and Hsieh [40] included innovation capital into the intellectual capital framework. Phusavat et al. [11] also extended 
VAIC by adding innovation capital. Ulum et al. [12] and Nimtrakoon [13] considered relational capital (RC) as the additional component of VAIC. Bayraktaroglu et al. [15] extended the VAIC model and applied innovation capital and customer capital as the two additional components of IC. Anifowose et al. [41,42] composed structural capital into relational capital, innovation capital, process capital, and protected capital.

Vishnu and Gupta [14] tested several modifications of VAIC. Firstly, they add relational capital as the third component of intellectual capital. Secondly, they change the way to measure SCE and RCE by using VA as the numerator. Thirdly, the authors test VAIC specifications that employed net sales instead of VA.

Kozera-Kowalska [20] agreed with the critique of Andriessen [16] regarding stock and flows confusion when the VAIC methodology is applied. In order to correct this flaw, the author creates intellectual sources of value added (ISVA) as the alternative methodology for intellectual capital estimation. As reported by Kozera-Kowalska [20], ISVA is based on calculations that rely solely on flows (streams), which is consistent with fundamental economic principles, in opposition to VAIC. However, the ISVA methodology does not allow estimating the value of intellectual capital elements. As well as VAIC, ISVA contains a set of return ratios.

Thereby, researchers have been mainly interested in finding new components of intellectual capital. The equations of efficiency ratios, VA and VAIC have been also subject to various modifications. However, financial methods for intellectual capital assessment have not allowed estimating the stock entities yet. The next section attempts to fill this gap.

\section{Introducing New Intellectual Capital Measures}

\subsection{Intellectual Capital of a Firm in a Perfectly Competitive Setting}

Bassetti et al. [19] conducted an analysis of VAIC when firms operate under conditions of perfect competition. We argue that this approach is very useful and apply it in our study.

The standard Cobb-Douglas production function assumes that the final output results from labor, physical capital and intermediate goods:

$$
\mathrm{Y}_{\mathrm{t}}=\mathrm{F}\left(\mathrm{L}_{\mathrm{t}}, \mathrm{K}_{\mathrm{t}}, \mathrm{I}_{\mathrm{t}}\right)=\mathrm{AL}_{\mathrm{t}}^{\alpha} \mathrm{K}_{\mathrm{t}}^{\beta} \mathrm{I}_{\mathrm{t}}^{\gamma}
$$

where $\mathrm{Y}$ is the total output, $\mathrm{A}$ is the state of technology, $\mathrm{L}$ is the total amount of employees, $\mathrm{K}$ is the stock of physical capital, I is the flow of intermediate good and $\alpha, \beta$, and $\gamma$ are the elasticity coefficients of labor, physical capital, and intermediate good.

Components of intellectual capital can be added into the standard production function. As well as the original VAIC model, our study takes only human capital and structural capital under consideration.

Firms can increase their output by hiring more employees or by increasing their abilities and skills. Every one of the companies' personnel contributes part of their human capital to the overall stock of human capital hired by firms. Therefore, the stock of human capital can be defined as:

$$
\mathrm{K}_{\mathrm{HC}, \mathrm{t}}=\mathrm{k}_{\mathrm{HC}, \mathrm{t}} \mathrm{L}_{\mathrm{t}}
$$

where $\mathrm{K}_{\mathrm{HC}}$ is the overall stock of human capital applied by a company, $\mathrm{k}_{\mathrm{HC}}$ is the stock of human capital per employee.

Structural capital belongs to firms and increases efficiency of physical capital usage. Thus, the overall stock of structural capital can be defined as follows:

$$
\mathrm{K}_{\mathrm{SC}, \mathrm{t}}=\mathrm{k}_{\mathrm{SC}, \mathrm{t}} \mathrm{K}_{\mathrm{t}}
$$

where $\mathrm{K}_{\mathrm{SC}}$ is the overall stock of structural capital owned by a company, and $\mathrm{k}_{\mathrm{SC}}$ is the stock of structural capital per unit of physical capital. 
When components of intellectual capital are taken under consideration, the equation of the total output can be defined as follows:

$$
\mathrm{Y}_{\mathrm{t}}=\mathrm{AK}_{\mathrm{HC}, \mathrm{t}}^{\alpha} \mathrm{K}_{\mathrm{SC}, \mathrm{t}}^{\beta} \mathrm{I}_{\mathrm{t}}^{\gamma}
$$

where $\alpha$ and $\beta$ are the elasticity coefficients of human capital and structural capital.

Most of the studies that deal with intellectual capital admit that IC and its components positively affect not only the level of output but increase the efficiency level. The more human capital is concentrated in each employee, the higher the efficiency of the business unit is. The same is true for structural capital. However, Equation (11) does not represent this relationship. In order to fix this problem, our study presents parameter $\mathrm{A}$ as the following function:

$$
\mathrm{A}=\mathrm{ak}_{\mathrm{HC}, \mathrm{t}} \mathrm{k}_{\mathrm{SC}, \mathrm{t}}
$$

Thus, the production function of the total output with respect to Equation (12) can be defined as the follows:

$$
\mathrm{Y}_{\mathrm{t}}=\mathrm{ak}_{\mathrm{HC}, \mathrm{t}} \mathrm{k}_{\mathrm{SC}, \mathrm{t}} \mathrm{K}_{\mathrm{HC}, \mathrm{t}}^{\alpha} \mathrm{K}_{\mathrm{SC}, \mathrm{t}}^{\beta} \mathrm{t}_{\mathrm{t}}^{\gamma}=\mathrm{aL}_{\mathrm{t}}^{\alpha} \mathrm{k}_{\mathrm{HC}, \mathrm{t}}^{(1+\alpha)} \mathrm{K}_{\mathrm{t}}^{\beta} \mathrm{k}_{\mathrm{SC}, \mathrm{t}}^{(1+\beta)} \mathrm{I}_{\mathrm{t}}^{\gamma}
$$

The optimization problem of a firm is to choose human capital and structural capital as to maximize profit:

$$
\max \pi_{\mathrm{t}}=\mathrm{Y}_{\mathrm{t}}-\mathrm{r}_{\mathrm{HC}, \mathrm{t}} \mathrm{K}_{\mathrm{HC}, \mathrm{t}}-\mathrm{r}_{\mathrm{SC}, \mathrm{t}} \mathrm{K}_{\mathrm{SC}, \mathrm{t}}-\mathrm{I}_{\mathrm{t}}
$$

where $r_{\mathrm{HC}, t}$ is the cost of human capital and $\mathrm{r}_{\mathrm{SC}, \mathrm{t}}$ is the cost of structural capital.

In the long run, the assumption of a perfectly competitive market implies no economic profits. The marginal product of human and structural capital is equal to the cost of human and structural capital, respectively. If $\pi_{t}$ is equal to zero, then:

$$
\mathrm{Y}_{\mathrm{t}}=\mathrm{r}_{\mathrm{HC}, \mathrm{t}} \mathrm{K}_{\mathrm{HC}, \mathrm{t}}+\mathrm{r}_{\mathrm{SC}, \mathrm{t}} \mathrm{K}_{\mathrm{SC}, \mathrm{t}}+\mathrm{I}_{\mathrm{t}}
$$

Thus, the final output contains the income of the human capital owners and the income of the structural capital owners. Employees (human capital owners) receive wages and salaries that are defined as $\mathrm{HC}$ in the original VAIC model. As for the structural capital owners, their income is defined as SC in the original VAIC model. Therefore:

$$
\begin{gathered}
\mathrm{r}_{\mathrm{HC}, \mathrm{t}} \mathrm{K}_{\mathrm{HC}, \mathrm{t}}=\mathrm{HC}_{\mathrm{t}} \\
\mathrm{r}_{\mathrm{SC}, \mathrm{t}} \mathrm{K}_{\mathrm{SC}, \mathrm{t}}=\mathrm{SC}_{\mathrm{t}}
\end{gathered}
$$

where HC is the income from the use of human capital (wages and salaries), and SC is the income from the use of structural capital (sum of depreciation, amortization and operating profit).

Therefore, Equation (15) becomes:

$$
\mathrm{Y}_{\mathrm{t}}=\mathrm{HC}_{\mathrm{t}}+\mathrm{SC}_{\mathrm{t}}+\mathrm{I}_{\mathrm{t}}=\mathrm{VA}_{\mathrm{t}}+\mathrm{I}_{\mathrm{t}}
$$

\subsection{Theoretical Decomposition of the Original VAIC Model}

The original VAIC model defines intellectual capital efficiency (ICE) as the sum of human capital efficiency (HCE) and structural capital efficiency (SCE). HCE is the ratio of VA to HC, and SCE is the ratio of VA to SC. This section decomposes the equations of ICE, HCE and SCE in order to show determinants of these ratios when firms operate in perfectly competitive markets.

Given Equations (17) and (18), the SCE equation can be defined as follows:

$$
\mathrm{SCE}=\frac{\mathrm{SC}}{\mathrm{VA}}=\frac{\mathrm{r}_{\mathrm{SC}} \mathrm{K}_{\mathrm{SC}}}{\mathrm{r}_{\mathrm{HC}} \mathrm{K}_{\mathrm{HC}}+\mathrm{r}_{\mathrm{SC}} \mathrm{K}_{\mathrm{SC}}}=\frac{1}{1+\frac{\mathrm{r}_{\mathrm{HC}} \mathrm{K}_{\mathrm{HC}}}{\mathrm{r}_{\mathrm{SC}} \mathrm{K}_{\mathrm{SC}}}}
$$


SCE positively depends on the stock of structural capital and the cost of structural capital. Moreover, SCE negatively depends on the ratio of $r_{\mathrm{HC}} \mathrm{K}_{\mathrm{HC}}$ to $\mathrm{r}_{\mathrm{SC}} \mathrm{K}_{\mathrm{SC}}$. If a firm prefers to use human capital more than structural capital and pays employees well, then SCE will be relatively small.

Thus, SCE represents the following: (1) the ratio of the cost of structural capital to the cost of human capital; and (2) the size of the structural capital stock relative to the size of the stock of human capital. This is consistent with the Andriessen's criticism [16]. SCE does not show the contribution of structural capital to financial performance and value creation.

HCE should be analyzed as well. Given Equations (16) and (18), the HCE equation is defined as follows:

$$
\mathrm{HCE}=\frac{\mathrm{VA}}{\mathrm{HC}}=\frac{\mathrm{Y}-\mathrm{pI}}{\mathrm{r}_{\mathrm{HC}} \mathrm{K}_{\mathrm{HC}}}=\frac{\mathrm{r}_{\mathrm{HC}} \mathrm{K}_{\mathrm{HC}}+\mathrm{r}_{\mathrm{SC}} \mathrm{K}_{\mathrm{SC}}}{\mathrm{r}_{\mathrm{HC}} \mathrm{K}_{\mathrm{HC}}}=1+\frac{\mathrm{r}_{\mathrm{SC}} \mathrm{K}_{\mathrm{SC}}}{\mathrm{r}_{\mathrm{HC}} \mathrm{K}_{\mathrm{HC}}}
$$

Equation (20) shows that HCE is positively associated with the cost of structural capital and its stock. However, HCE is inversely proportional to the stock of human capital and its cost. When companies hire more qualified staff and pay them a lot due to the high level of knowledge, HCE actually falls. Thus, HCE does not represent employees knowledge and competence and does not show how big the stock of human capital is.

HCE and SCE just represent the ratio of the income from the use of structural capital relative to the income from the use of human capital. According to the theoretical analysis, there is no sense in estimating both SCE and HCE because these ratios measure the same thing and just duplicate each other.

ICE is the simple sum of HCE and SCE:

$$
\mathrm{ICE}=\mathrm{HCE}+\mathrm{SCE}=1+\frac{\mathrm{r}_{\mathrm{SC}} \mathrm{K}_{\mathrm{SC}}}{\mathrm{r}_{\mathrm{HC}} \mathrm{K}_{\mathrm{HC}}}+\frac{1}{1+\frac{\mathrm{r}_{\mathrm{HC}} \mathrm{K}_{\mathrm{HC}}}{\mathrm{r}_{\mathrm{SC}} \mathrm{K}_{\mathrm{SC}}}}
$$

Equation (21) shows that firms with a large stock of human capital will have smaller ICE than firms with the small one. In an attempt to evaluate intellectual capital, the VAIC model represents the stock of human capital as the negative factor. As the result, a slightly paradoxical situation arises. On the one hand, human capital is recognized as the important element of intellectual capital and the source of competitive advantage and value. On the other hand, the stock of human capital negatively affects intellectual capital efficiency when computing ICE.

As for the capital employed efficiency, its equation (with respect to Equation (18) and given that $\mathrm{CE}$ is equal to $\mathrm{K}$ ) can be defined as follows:

$$
\mathrm{CEE}=\frac{\mathrm{VA}}{\mathrm{CE}}=\frac{\mathrm{r}_{\mathrm{HC}} \mathrm{K}_{\mathrm{HC}}+\mathrm{r}_{\mathrm{SC}} \mathrm{K}_{\mathrm{SC}}}{\mathrm{K}}=\mathrm{r}_{\mathrm{SC}} \mathrm{k}_{\mathrm{SC}}+\frac{\mathrm{r}_{\mathrm{HC}} \mathrm{K}_{\mathrm{HC}}}{\mathrm{K}}=\mathrm{r}_{\mathrm{SC}} \mathrm{k}_{\mathrm{SC}}+\frac{\mathrm{HC}}{\mathrm{K}}
$$

Equation (22) show that CEE has a positive connection to the cost and stock of both human and structural capital. It can be suggested that the ratio of $\mathrm{HC}$ to $\mathrm{K}$ is relatively small, that is why structural capital affects CEE to a greater degree than human capital.

The analysis reveals that VAIC (as well as the VAIC modifications and ISVA) fails to demonstrate both the value of intellectual capital and the efficiency of its usage. HCE and SCE just represent the ratio of structural capital to human capital. HCE and SCE do not demonstrate the marginal product of human and structural capital.

\subsection{Valuation of Intellectual Capital and Its Elements}

Previously, this article defined the production function in which the total output resulted from the stock of human capital, the stock of structural capital, and the flow of the intermediate good. Regression analysis of this production function can help to 
estimate human capital and structural capital. Equation (11) can be transformed in the log-linear equation:

$$
\ln \left(\mathrm{Y}_{\mathrm{t}}\right)=\ln (\mathrm{A})+\alpha \ln \left(\mathrm{K}_{\mathrm{HC}, \mathrm{t}}\right)+\beta \ln \left(\mathrm{K}_{\mathrm{SC}, \mathrm{t}}\right)+\gamma \ln \left(\mathrm{I}_{\mathrm{t}}\right)
$$

Using Equations (13) and (23) yields:

$$
\ln \left(\mathrm{Y}_{\mathrm{t}}\right)=\ln (\mathrm{a})+(1+\alpha) \ln \left(\mathrm{k}_{\mathrm{HC}}\right)+\alpha \ln \left(\mathrm{L}_{\mathrm{t}}\right)+(1+\beta) \ln \left(\mathrm{k}_{\mathrm{SC}}\right)+\beta \ln \left(\mathrm{K}_{\mathrm{t}}\right)+\gamma \ln \left(\mathrm{I}_{\mathrm{t}}\right)
$$

Many studies use regression analysis to estimate the elasticity coefficients and the state of technology. Usually, $\mathrm{A}, \alpha, \beta$, and $\gamma$ are assumed to be unobservable while information related to the amount of inputs that define the final output $(\mathrm{L}, \mathrm{K}$, and I) is available. However, the situation gets more complicated when it comes to the estimation of intellectual capital elements. In this case, two new unobservable variables are added $\left(\mathrm{k}_{\mathrm{HC}}\right.$ and $\left.\mathrm{k}_{\mathrm{SC}}\right)$. The equation becomes overloaded with unobservables that need to be evaluated.

In the long run and in a perfectly competitive market the elasticity coefficients $\alpha, \beta$, and $\gamma$ are equal to the human capital, structural capital and intermediate goods shares in the total output, respectively:

$$
\begin{gathered}
\alpha_{t}=\frac{H C_{t}}{Y_{t}} \\
\beta_{t}=\frac{S C_{t}}{Y_{t}} \\
\gamma_{t}=\frac{I_{t}}{Y_{t}}
\end{gathered}
$$

When elasticity coefficients are estimated in each period, the log-linear equation is defined as follows:

$$
\ln \left(\mathrm{Y}_{\mathrm{t}}\right)=\ln (\mathrm{a})+\left(1+\alpha_{\mathrm{t}}\right) \ln \left(\mathrm{k}_{\mathrm{HC}}\right)+\alpha_{\mathrm{t}} \ln \left(\mathrm{L}_{\mathrm{t}}\right)+\left(1+\beta_{\mathrm{t}}\right) \ln \left(\mathrm{k}_{\mathrm{SC}}\right)+\beta_{\mathrm{t}} \ln \left(\mathrm{K}_{\mathrm{t}}\right)+\gamma_{\mathrm{t}} \ln \left(\mathrm{I}_{\mathrm{t}}\right)
$$

Move known variables to the left and leave unknowns to the right:

$$
\ln \left(\mathrm{Y}_{\mathrm{t}}\right)-\alpha_{\mathrm{t}} \ln \left(\mathrm{L}_{\mathrm{t}}\right)-\beta_{\mathrm{t}} \ln \left(\mathrm{K}_{\mathrm{t}}\right)-\gamma_{\mathrm{t}} \ln \left(\mathrm{I}_{\mathrm{t}}\right)=\ln (\mathrm{a})+\left(1+\alpha_{\mathrm{t}}\right) \ln \left(\mathrm{k}_{\mathrm{HC}}\right)+\left(1+\beta_{\mathrm{t}}\right) \ln \left(\mathrm{k}_{\mathrm{SC}}\right)
$$

$\mathrm{k}_{\mathrm{HC}}$ and $\mathrm{k}_{\mathrm{SC}}$ can be evaluated when OLS (ordinary least squares) is applied for the estimation of Equation (29).

It is worth noting that Shakina and Barajas [40] employed the Cobb-Douglas framework and OLS in order to estimate the elasticity of intellectual capital output. However, the current study applies a slightly different approach, when elasticity coefficients are calculated before running OLS in order to evaluate the stock of human capital per employee and the stock of structural capital per unit of physical capital with regression analysis.

The suggested method of estimating the stock of human capital $\left(\mathrm{k}_{\mathrm{HC}}\right)$ and the stock of structural capital $\left(\mathrm{k}_{\mathrm{SC}}\right)$ allows identifying factors that affect the production process and are not associated with intellectual capital. It can be assumed that the variable $\ln (a)$ is able to catch these other factors when empirically testing Equation (29).

Also, the suggested method separates the stock and flow entities. $\mathrm{k}_{\mathrm{HC}}$ and $\mathrm{k}_{\mathrm{SC}}$ represent the stock of intellectual capital components while $\mathrm{r}_{\mathrm{HC}}$ (the cost or marginal product of human capital) and $\mathrm{r}_{\mathrm{SC}}$ (the cost or marginal product of structural capital) show the efficiency of the usage of human capital and structural capital. Knowing $\mathrm{k}_{\mathrm{SC}}$ and $\mathrm{k}_{\mathrm{HC}}$, it is easy to compute $\mathrm{r}_{\mathrm{SC}}$ and $\mathrm{r}_{\mathrm{HC}}$ :

$$
\begin{aligned}
& r_{S C}=\beta_{t} \frac{A\left(K_{H C, t}\right)^{\alpha_{t}} I_{t}^{\gamma_{t}}}{\left(K_{S C, t}\right)^{\left(1-\beta_{t}\right)}} \\
& r_{H C}=\alpha_{t} \frac{A\left(K_{S C, t}\right)^{\beta_{t}} I_{t}^{\gamma_{t}}}{\left(K_{H C, t}\right)^{\left(1-\alpha_{t}\right)}}
\end{aligned}
$$


In contradiction to SCE and $\mathrm{HCE}, \mathrm{r}_{\mathrm{SC}}$ and $\mathrm{r}_{\mathrm{HC}}$ allow estimating efficiency ratios of structural and human capital separately. As the analysis showed, SCE and HCE are, in fact, the same indicators that represent the ratio of $\mathrm{r}_{\mathrm{SC}} \mathrm{K}_{\mathrm{SC}}$ to $\mathrm{r}_{\mathrm{HC}} \mathrm{K}_{\mathrm{HC}}$. The difference between SCE and HCE is only in scale. However, $\mathrm{r}_{\mathrm{SC}}$ and $\mathrm{r}_{\mathrm{HC}}$ represent truly different things.

The suggested method of intellectual capital elements estimation is free of the criticism that VAIC faces [16-18]. The stock and flow entities can be evaluated separately now. $\mathrm{k}_{\mathrm{SC}}$ and $\mathrm{k}_{\mathrm{HC}}$ estimate the value of structural and human capital themselves while $\mathrm{r}_{\mathrm{SC}}$ and $\mathrm{r}_{\mathrm{HC}}$ represent their efficiency ratios. Table 1 summarizes the main differences in the approaches to the assessment of intellectual capital.

Table 1. Comparative analysis of approaches to the assessment of intellectual capital. VAIC, value-added intellectual coefficient; IC, intellectual coefficient; HCE, human capital efficiency; SCE, structural capital efficiency.

\begin{tabular}{lll}
\hline & \multicolumn{1}{c}{$\begin{array}{c}\text { The VAIC Approach (the Most Popular } \\
\text { Financial Approach to IC Estimation) }\end{array}$} & \multicolumn{1}{c}{ The Authors' Approach } \\
Simplicity & $\begin{array}{l}\text { Simple approach. Only financial ratios } \\
\text { are calculated. }\end{array}$ & $\begin{array}{l}\text { Complicated approach. IC elements are calculated } \\
\text { with ordinary least squares (OLS) applied to the } \\
\text { special production function. }\end{array}$ \\
\hline $\begin{array}{l}\text { Separating stock and } \\
\text { flow entities }\end{array}$ & $\begin{array}{l}\text { Stock and flow entities are confused. HCE and } \\
\text { SCE mix the stock of IC elements and the cost } \\
\text { of IC elements. }\end{array}$ & $\begin{array}{l}\text { Stock and flow entities are separated. The } \\
\text { suggested method allows calculating both the } \\
\text { stock and the cost of structural and human capital. }\end{array}$ \\
\hline $\begin{array}{l}\text { Information about the } \\
\text { contribution of IC } \\
\text { elements to value creation }\end{array}$ & $\begin{array}{l}\text { VAIC ratios does not provide such information. } \\
\text { HCE and SCE does not separate stocks and } \\
\text { flows. Moreover, SCE and HCE duplicate each } \\
\text { other and show just the income from the use of } \\
\text { structural capital relative to the income from } \\
\text { the use of human capital. }\end{array}$ & $\begin{array}{l}\text { Full information about the contribution of IC } \\
\text { elements to value creation can be provided. } \\
\text { investigating how the stock of IC elements and the } \\
\text { cost of IC elements contribute to value creation. }\end{array}$ \\
\hline
\end{tabular}

\section{Materials and Methods}

\subsection{Sample}

We investigated Russian public agribusiness firms whose shares and bonds are traded on the Moscow Stock Exchange. These firms need to disclose financial reports according to the listing rules. The documents required (balance sheet and profit and loss (P\&L) account) provide a unified and reliable basis for calculations. This study covered the period from 2012 to 2019. Companies with negative book values of equity are excluded. Some companies may be exempted from financial disclosure as their securities are no longer traded on the stock exchange as of the end of 2019. Such companies just do not deliver enough data, so they are excluded as well. After excluding, the final sample consist of 10 companies. Thus, 320 firm $x$ quarter observations are used in the research. The final sample consist of firms that operates in animal husbandry, crop production, dairy production, fish production, and marketing of agricultural products.

\subsection{Measures of Firm Performance}

There are many indicators that represent the level of profitability. The most frequently used firm performance indicators are:

(1) The ratio of net income to book value of total assets (rent on assets; ROA) [37].

(2) The ratio of net income to total shareholders' equity (rent on equity; ROE) [37].

(3) The ratio of total revenue to book value of total assets (assets turnover; ATO) [43]

Fama and French [44] applied operating profitability or OP (the ratio of operating profit to book value of total assets) as the indicator of firms' profitability or financial success. As noted by Novy-Marx [45], the farther down the income statement one goes, the more polluted profitability measures become, and the less related they are to true economic profitability. Guided by this logic, Novy-Marx [45] applied gross profitability (ratio of gross profit to assets) as the measure of financial performance. 
In order to conduct the analysis, the following indicators of firms' performance were chosen: OP and GP. Our study does not apply ROE. This indicator is inappropriate when the book value of equity turns negative. The use of GP and OP is not burdened with this problem. ATO is also not a very good measure of the profitability level. A firm may reduce its output while the profitability level will stay stable due to the cost reduction.

\subsection{Measures of Intellectual Capital, Hypotheses and Empirical Model}

Most of the articles deal with VAIC's ratios when testing the relationship between firm performance and intellectual capital (measured with financial methods). However, the set of intellectual capital measures is wider in this article. In the previous section, two kinds of intellectual capital measures were introduced: the first one represents the stock measures $\left(\mathrm{k}_{\mathrm{SC}}\right.$ and $\left.\mathrm{k}_{\mathrm{HC}}\right)$ while the second one represents efficiency measures ( $\mathrm{r}_{\mathrm{SC}}$ and $\mathrm{r}_{\mathrm{HC}}$ ) that can be estimated based on $\mathrm{k}_{\mathrm{SC}}$ and $\mathrm{k}_{\mathrm{HC}}$.

The following hypotheses are made:

Hypothesis 1 (H1). The cost of structural capital positively affects firm performance. The cost of structural capital measures effectiveness of structural capital that belongs to the firm. Thus, all the benefits received from structural capital usage stays inside the firm.

Hypothesis 2 (H2). The cost of human capital does not affect firm performance. As for the cost of human capital, its influence can be different. On the one hand, $r_{H C}$ measures effectiveness of the usage of the human capital stock and, therefore, should be positively associated with profit and firm performance. On the other hand, the cost of human capital is the price that firms pay to the human capital owners. Thus, $r_{H C}$ may negatively affect the current level of profitability.

Hypothesis 3 (H3). The stock of human capital per employee $\left(k_{H C}\right)$ and the stock of structural capital per unit of physical capital $\left(k_{S C}\right)$ positively affect firm performance.

Hypothesis 4 (H4). $r_{S C}$ and $r_{H C}$ are more statistically significant than the VAIC's ratios. The theoretical analysis has shown inconsistency of HCE and SCE. However, VAIC is very popular among researchers and demonstrates good results when empirically tested. In order to compete with VAIC, the proposed intellectual capital measures should reveal greater statistical significance.

The following regression model is going to be tested:

$$
\mathrm{P}=\mathrm{b}_{0}+\mathrm{b}_{1} \mathrm{P}_{\mathrm{t}-1}+\mathrm{b}_{2} \mathrm{r}_{\mathrm{HC}}+\mathrm{b}_{3} \mathrm{r}_{\mathrm{SC}}+\mathrm{b}_{4} \mathrm{SCE}+\mathrm{b}_{5} \mathrm{HCE}+\mathrm{b}_{6} \mathrm{k}_{\mathrm{HC}}+\mathrm{b}_{7} \mathrm{k}_{\mathrm{SC}}+\mathrm{b}_{8} \mathrm{a}+\mathrm{b}_{9} \text { size }
$$

where P represents firm performance (OP or GP). Size and a are control variables. a represents all other factors that affect the level of financial performance. In fact, a is estimated for each firm when empirically testing Equation (29) with OLS. In addition, we controled for firm size by the book value of total assets. Company size matters for intangible driven performance [46].

\subsection{Method of Parameters Estimation}

SystemGMM (general method of moments) is used as an estimator in the present study [47-50]. System-GMM combines equation in first difference and equation in level, which enhances its efficiency. GMM has the capacity to overcome the problem of endogeneity of variables that is commonly observed in corporate governance researches [51].

\section{Results}

Firstly, all quarterly data were smoothed in order to get rid of the seasonality effect. Thus, at the end of each quarter, we used the 4-quarter average. Secondly, all of the proposed measures of intellectual capital $\left(\mathrm{k}_{\mathrm{SC}}, \mathrm{k}_{\mathrm{HC}}, \mathrm{r}_{\mathrm{SC}}\right.$ and $\left.\mathrm{r}_{\mathrm{HC}}\right)$ were estimated by applying OLS to Equation (29). All approximations for Y, K, L, and I are given in Table 2. 
Table 2. Balance sheet and P\&L account approximations.

\begin{tabular}{cr}
\hline Variable & Approximation (Balance Sheet and P\&L Account) \\
\hline $\mathrm{Y}$ & Total revenue (in millions of RUB) \\
\hline $\mathrm{K}$ & Book value of total assets (in millions of RUB) \\
\hline $\mathrm{L}$ & Total personnel, millions of people \\
\hline $\mathrm{I}$ & $\begin{array}{r}\text { Total revenue minus personnel expenses, operating profit, } \\
\text { amortization and depreciation (in millions of RUB) }\end{array}$ \\
\hline
\end{tabular}

Secondly, SCE, CEE, and HCE have been calculated according to the original VAIC approach. The descriptive statistics results of measured dependent and independent variables are given in Table 3. According to the results, since all variables have positive mean values, it can be said that the agribusiness has positive performance and intellectual capital levels on average. The standard deviation and minimum and maximum values presented in Table 1 indicate that there is notably high variability in the data. Human capital per employee $\left(\mathrm{k}_{\mathrm{HC}}\right)$ has the biggest mean value among presented measures. It can be said that the agricultural firms hire an employee that owns human capital in the amount of 1,092,286 million rubles, in average. As for $\mathrm{k}_{\mathrm{SC}}$, an average firm owns 0.233 million rubles of structural capital per 1 million rubles of physical capital. The cost of human capital, as well as the stock of human capital per employee, has a high mean value relative to other variables. The reason is that the overall stock of human capital $\left(\mathrm{K}_{\mathrm{HC}}\right)$ is many times lower than the overall stock of structural capital $\left(\mathrm{K}_{\mathrm{SC}}\right)$ (when it comes to $\mathrm{k}_{\mathrm{HC}}$ and $\mathrm{k}_{\mathrm{SC}}$ the situation is different).

Table 3. Descriptive statistics of VAIC ratios, suggested IC measures, and profitability measures.

\begin{tabular}{cccccc}
\hline Variable & Obs. & Mean & Std. Dev. & Min & Max \\
\hline GP & 320 & 0.051 & 0.0332 & -0.116 & 0.1474 \\
\hline OP & 320 & 0.028 & 0.0218 & -0.0484 & 0.1299 \\
\hline khc & 320 & $1,092,286$ & $2,872,187$ & 1 & $9,683,171$ \\
\hline ksc & 320 & 0.233 & 0.128 & 0.0568 & 0.45203 \\
\hline rhc & 320 & 265,48 & 773,085 & 0.0082 & 4872,76 \\
\hline rsc & 320 & 0.257 & 0.5296 & -0.166 & 6823 \\
\hline SCE & 320 & 0.66 & 0.3063 & -1.39 & 1845 \\
\hline HCE & 320 & 7.12 & 12,152 & -1.18 & 75.87 \\
\hline a & 320 & 0.103 & 0.2996 & $3.97 \times 10^{-7}$ & 1 \\
\hline size & 320 & 10,405 & 16,138 & 7204 & 12,634 \\
\hline
\end{tabular}

The effects of IC measures on firm performance were analyzed using the system GMM estimator. Results are given in Table 4. It contains t-statistic values and p-values in order to demonstrate significance. The second order serial correlation tests were performed, since GMM can only produce reliable estimates if there is no second order serial correlation in the error terms. The Arellano-Bond test confirmed the absence of second order serial correlation in the error. In addition, the Hansen test confirmed the validity of instruments. Significant F-values were observed in all tested regression models. Asterisks indicate the level of significance: $* 10 \%$ significance, ${ }^{* *} 5 \%$ significance, ${ }^{* * *} 1 \%$ significance. 
Table 4. Regression results.

\begin{tabular}{|c|c|c|}
\hline Model Number & Model 1 & Model 2 \\
\hline Firm performance measure & $\mathrm{OP}$ & GP \\
\hline $\begin{array}{c}\text { b0 (const) } \\
\text { (t-stat.) }\end{array}$ & $\begin{array}{c}-0.011^{* *} \\
(-2.69)\end{array}$ & $\begin{array}{c}-0.014 * * \\
(-2.96)\end{array}$ \\
\hline $\begin{array}{l}\mathrm{b} 1\left(\mathrm{P}_{\mathrm{t}-1}\right) \\
\text { (t-stat.) }\end{array}$ & $\begin{array}{l}0.774^{* * *} \\
(22.69)\end{array}$ & $\begin{array}{l}0.947 * * * \\
(19.74)\end{array}$ \\
\hline $\begin{array}{l}\mathrm{b} 2\left(\mathrm{r}_{\mathrm{HC}}\right) \\
\text { (t-stat.) }\end{array}$ & $\begin{array}{c}-2.94 \times 10^{-7} \\
(-0.34)\end{array}$ & $\begin{array}{c}-1.05 \times 10^{-6} \\
(-0.56)\end{array}$ \\
\hline $\begin{array}{l}\text { b3 (rsc) } \\
\text { (t-stat.) }\end{array}$ & $\begin{array}{l}0.0091^{* * *} \\
(14.65)\end{array}$ & $\begin{array}{l}0.0096^{* * *} \\
(8.5)\end{array}$ \\
\hline $\begin{array}{l}\text { b4 (SCE) } \\
\text { (t-stat.) }\end{array}$ & $\begin{array}{c}-0.0082 \\
(1.54)\end{array}$ & $\begin{array}{l}0.0028 \\
(0.55)\end{array}$ \\
\hline $\begin{array}{l}\text { b5 (HCE) } \\
\text { (t-stat.) }\end{array}$ & $\begin{array}{c}0.00025^{* *} \\
(2.78)\end{array}$ & $\begin{array}{c}0.00009 \\
(1.02)\end{array}$ \\
\hline $\begin{array}{c}\text { b6 }\left(\mathrm{k}_{\mathrm{HC}}\right) \\
\text { (t-stat.) }\end{array}$ & $\begin{array}{c}2.09 \times 10^{-10 * *} \\
(2.27)\end{array}$ & $\begin{array}{c}2.64 \times 10^{-10 *} \\
(2.07)\end{array}$ \\
\hline $\begin{array}{c}\left.\text { b7 ( } \mathrm{k}_{\mathrm{SC}}\right) \\
\text { (t-stat.) }\end{array}$ & $\begin{array}{c}0.0052 \\
(0.75)\end{array}$ & $\begin{array}{c}0.0042 \\
(0.78)\end{array}$ \\
\hline $\begin{array}{l}\text { b8 (a) } \\
\text { (t-stat.) }\end{array}$ & $\begin{array}{l}-0.0115^{* *} \\
(-2.63)\end{array}$ & $\begin{array}{l}-0.0003 \\
(-0.04)\end{array}$ \\
\hline $\begin{array}{l}\text { b9 (size) } \\
\text { (t-stat.) }\end{array}$ & $\begin{array}{c}0.00076 \\
(1.52)\end{array}$ & $\begin{array}{c}0.0009 \\
(1.48)\end{array}$ \\
\hline $\begin{array}{c}\text { AR(1) } \\
p \text { value }\end{array}$ & 0.137 & 0.075 \\
\hline $\begin{array}{c}\mathrm{AR}(2) \\
p \text { value }\end{array}$ & 0.264 & 0.263 \\
\hline $\begin{array}{l}\text { F-value } \\
\text { Prob }>\text { F }\end{array}$ & $\begin{array}{c}5899.1 \\
0.000\end{array}$ & $\begin{array}{c}7144.91 \\
0.000\end{array}$ \\
\hline $\begin{array}{l}\text { Hansen test for overid. } \\
\text { restrictions }\end{array}$ & 0.999 & 0.999 \\
\hline $\begin{array}{l}\text { Hansen test of exogeneity of } \\
\text { instrument subsets ( } p \text { value): } \\
\text { - } \quad \text { for levels } \\
\text { - } \quad \text { for first differences }\end{array}$ & $\begin{array}{l}0.999 \\
0.999\end{array}$ & $\begin{array}{l}0.999 \\
0.999\end{array}$ \\
\hline
\end{tabular}

According to the results, the most significant IC measure is the cost of structural capital $\left(\mathrm{r}_{\mathrm{SC}}\right) . \mathrm{r}_{\mathrm{SC}}$ is significant at $1 \%$ level in Model 1 and Model 2 . Among the authors' IC measures, $\mathrm{k}_{\mathrm{HC}}$ also shows significance at $10 \%$ level (Model 2) and at $5 \%$ level (Model 2). As for the VAIC ratios, HCE is statistically significant in 5\% level only in the case of Model 1. When Model 2 is taken under consideration, HCE and SCE are both insignificant. It can be concluded that the profitability level of Russian agricultural firms (presented with gross profitability and operating profitability) is positively affected by the cost of structural capital and the stock of human capital.

$\mathrm{H} 1$ can be confirmed due to significance of the cost of structural capital. The cost of human capital does not affect GP and OP. Thus, H2 is also confirmed. The stock of human capital per employee affects the profitability level and the stock of structural capital per unit of physical capital does not. Thus, $\mathrm{H} 4$ is partially confirmed.

As for the VAIC ratios, HCE is the only ratio that affects firms' profitability significantly (Model 1). HCE is assumed to be the ratio that represents efficiency of human capital usage. However, our theoretical analysis of VAIC has shown that HCE (as well as SCE) is the ratio that represents efficiency of structural capital usage relative to human capital usage. We introduced the cost of structural capital $\left(\mathrm{r}_{\mathrm{SC}}\right)$ as an alternative measure of the efficiency of structural capital usage. $\mathrm{r}_{\mathrm{SC}}$ shows greater significance relative to HCE and SCE. The cost 
of human capital is statistically insignificant. However, the VAIC methodology does not contain any ratio similar to $\mathrm{r}_{\mathrm{HC}}$. Thus, $\mathrm{H} 4$ is confirmed.

\section{Discussion and Conclusions}

Approaches to IC estimation that use financial reports (especially the VAIC model) are always criticized in many aspects. In our study, we attempted to develop a method of intellectual capital estimation that does not contain the disadvantages of financial methods of IC evaluation.

The literature review provided in the study revealed that VAIC (the most popular financial method of IC estimation) has disadvantages that cast doubt on the appropriateness of its use. VAIC confuses stocks and flows, and does not provide information about the contribution of IC elements to value creation and variables which are not related to intellectual capital can affect VAIC [16].

In addition, the theoretical analysis provided in our study showed that the VAIC ratios (used in the original VAIC model) are actually the same indicators and weakly related to the efficiency of use of human and structural capital. High values of HCE and SCE mean that the cost and the stock of structural capital is many times higher than the cost and the stock of human capital.

Development of the method for assessing intellectual capital is one the main contributions of our study. The suggested method based on the Cobb-Douglas production function allows evaluating the stock of IC components and efficiency of IC components separately. The stock and the flow entities are no longer confused and variables that are not related to IC and can affect firm performance are separated. We theoretically introduced new IC financial measures and empirically proved their significance. Good theoretical and empirical results open up a great future for the novel developed method.

The Russian agribusiness was chosen as a case study for discovering the impact of intellectual capital components on the level of firm performance. Some authors have emphasized the lack of studies on IC in agriculture [20,22]. Agribusiness is heavily reliant on intellectual capital [21]. This article is not the first that investigates agribusiness [20-22,51,52]. However, the financial method of intellectual capital estimation that we suggested in the current study has many distinctive features in comparison with its analogues and it has never been applied to an agricultural sector. In addition, it is interesting to study Russian firms in general (and agricultural firms in particular), since they are characterized by a lack of intellectual capital and, as a result, a low level of competitiveness in comparison with foreign competitors [23].

As IC is the source of competitive advantage, suitable measures of IC should be associated with firms' financial performance positively. Profitable firms are more stable than unprofitable ones and have better protection from unforeseen economic shocks. For the Russian agribusiness firms, the most significant measure of IC is the cost of structural capital $\left(\mathrm{r}_{\mathrm{SC}}\right) . \mathrm{r}_{\mathrm{SC}}$ is significant at the $1 \%$ level and has the highest $\mathrm{t}$-statistics among IC measures. As for the stock measures, only the stock of human capital per employee $\left(\mathrm{k}_{\mathrm{HC}}\right)$ affects firms' performance significantly (at 5\% level in case of Model 1 and at $10 \%$ level in case of Model 2). According to Equation (30) with respect to Equation (9), the cost of structural capital is directly proportional to $\mathrm{k}_{\mathrm{HC}}$. Thus, the Russian agribusiness firms have to accumulate more human capital per employee. This will lead to the increased level of $\mathrm{r}_{\mathrm{SC}}$. As structural capital is owned by firms, the higher cost of structural capital will increase the level of profitability. The cost of human capital has no significant connection to the level of gross and operating profitability. Thus, it can be suggested that the Russian agribusiness firms can increase the level of employees' human capital and pay significantly without great harm to their profitability. Qualified staff must be well paid, but these losses can be compensated by an increased level of competitiveness.

The stock of human capital per employee is statistically significant in Model 1 at the 5\% level and in Model 2 at the 10\% level. The cost of human capital is statistically insignificant. Many studies report that human capital positively affects firm performance 
for many industries (including agribusiness) [4,6,11-15,21,40,41]. However, studies that use the VAIC methodology (or the modified VAIC methodology) employ HCE as the human capital efficiency measure. Our theoretical analysis showed that HCE represents neither the cost of human capital nor the stock of human capital. Actually, the authors' approach to IC elements estimation has been first introduced in the current article; therefore, it is a little difficult to talk about correlations with other articles. In any case, many papers that are related to IC and use different methodology always emphasize the role of human capital.

As we have shown in Section 3.2, HCE and SCE are positively connected to rSC. Our empirical analysis demonstrated that $\mathrm{r}_{\mathrm{SC}}$ is significant at the $1 \%$ level, positively affects the level of performance and has the highest t-statistic (14.65 in Model 1 and 8.5 in Model 2) relative to other IC measures. Thus, our results are in line with studies that employ the VAIC approach and report significance of SCE or HCE [11-15,40,41].

However, this study is subject to certain limitations, which could be an opportunity for future research. As only the publicly available data is applied, the study has limitations with regard to the measurement approach and the restricted sample of public companies.

A relatively small number of firms have generated the data, which is also a limitation of our study. Reports of public firms are a good source of information (due to stock exchange requirements), but a sample may be restricted when it comes to emerging markets such as Russia. The size of the sample used in the study may restrict the conclusions of the results. However, these result restrictions depend on intellectual capital measures. Some measures that the authors introduced have analogues that are well studied, and some measures do not have. In particular, the cost of structural capital is positively connected with HCE and SCE (Equations (19) and (20)). The VAIC model is well presented in the literature regarding intellectual capital and the significance of HCE and SCE has been proven in many studies. Thus, the results regarding significance of $\mathrm{r}_{\mathrm{SC}}$ should be considered reliable. As for the stock measures, $\mathrm{k}_{\mathrm{SC}}$ and $\mathrm{k}_{\mathrm{HC}}$ are first introduced in our study. Therefore, the results of studying these indicators can be considered as the first step towards the dissemination and wide application of the suggested approach to estimation of the stock of human capital and the stock of structural capital.

In any case, human capital and structural capital are recognized as important sources of firms' performance in many studies regardless of the measurement method. However, the suggested approach is novel, especially in terms of estimating the stock measures using financial reports. Further research will need a greater sample of companies that operate in different countries and industries to enhance the scientific validity and confirm the conclusions of both theoretical and empirical results of the suggested approach to IC estimation.

Another limitation of this study is related to the classification of the intellectual capital components. This study used only human capital and structural capital. However, modern classifications highlight more intellectual capital components, such as relational capital and innovational capital.

Author Contributions: The authors collaborated on methodology, formal analysis, experimental investigation, statistical analysis, and writing—original draft preparation. All authors have read and agreed to the published version of the manuscript.

Funding: This research was funded by Russian Foundation for Basic Research (RFBR), project number 20-011-00087, "Institutional factors and forms of rural development.

Institutional Review Board Statement: Not applicable.

Informed Consent Statement: Not applicable.

Data Availability Statement: No new data were created or analyzed in this study. Data sharing is not applicable to this article.

Conflicts of Interest: The authors declare no conflict of interest. 


\section{References}

1. Bontis, N. Intellectual capital: An exploratory study that develops measures and models. Manag. Decis. 1998, 36, 63-76. [CrossRef]

2. Hunter, L.; Webster, E.; Wyatt, A. Measuring intangible capital: A review of current practice. Aust. Account. Rev. 2005, 15, 4-21. [CrossRef]

3. Inkinen, H. Review of empirical research on intellectual capital and firm performance. J. Intellect. Cap. 2015, 16, 518-565. [CrossRef]

4. Gołacka, E.G.; Jefmańska, M.K.; Jefmański, B. Can Elements of Intellectual Capital Improve Business Sustainability?-The Perspective of Managers of SMEs in Poland. Sustainability 2020, 12, 1545. [CrossRef]

5. Cavicchi, C. Healthcare sustainability and the role of intellectual capital: Evidence from an Italian Regional Health Service. J. Intellect. Cap. 2017, 18, 544-563. [CrossRef]

6. Januškaite, V.; Užien, E.L. Intellectual Capital as a Factor of Sustainable Regional Competitiveness. Sustainability 2018, 10, 4848. [CrossRef]

7. Goebel, V. Estimating a measure of intellectual capital value to test its determinants. J. Intellect. Cap. 2015, 16, 101-120. [CrossRef]

8. Osinski, M.; Selig, P.M.; Matos, F.; Roman, D.J. Methods of evaluation of intangible assets and intellectual capital. J. Intellect. Cap. 2017, 18, 470-485. [CrossRef]

9. Ovechkin, D.; Boldyreva, N.; Davydenko, V. Intellectual capital and value: Testing new IC measures in Russia. J. Econ. Stud. 2020, 1, 17. [CrossRef]

10. Pedro, E.; Leitão, J.; Alves, H. Back to the future of intellectual capital research: A systematic literature review. Manag. Decis. 2018, 56, 2502-2583. [CrossRef]

11. Phusavat, K.; Comepa, N.; Lutek, A.S.; Ooi, K. Interrelationships between intellectual capital and performance. Ind. Manag. Data Syst. 2011, 111, 810-829. [CrossRef]

12. Ulum, I.; Ghozali, I.; Purwanto, A. Intellectual capital performance of Indonesian banking sector: A modified VAIC (M-VAIC) perspective. Asian J. Financ. Account. 2014, 6, 103-123. [CrossRef]

13. Nimtrakoon, S. The relationship between intellectual capital, firms' market value and financial performance-Empirical evidence from the ASEAN. J. Intellect. Cap. 2015, 16, 587-618. [CrossRef]

14. Vishnu, S.; Gupta, V.K. Intellectual capital and performance of pharmaceutical firms in India. J. Intellect. Cap. 2014, 15, 83-99. [CrossRef]

15. Bayraktaroglu, A.E.; Calisir, F.; Baskak, M. Intellectual capital and firm performance: An extended VAIC model. J. Intellect. Cap. 2019, 20, 406-425. [CrossRef]

16. Andriessen, D. Making Sense of Intellectual Capital: Designing a Method for the Valuation of Intangibles; Elsevier ButterworthHeinemann: Oxford, UK, 2004.

17. Stahle, P.; Stahle, S.; Aho, S. Value added intellectual coefficient (VAIC): A critical analysis. J. Intellect. Cap. 2011, 12, 531-551. [CrossRef]

18. Iazzolino, G.; Laise, D. Value added intellectual coefficient (VAIC)—A methodological and critical review. J. Intellect. Cap. 2013, 14, 547-563. [CrossRef]

19. Bassetti, T.; dal Maso, L.; Liberatore, G.; Mazzi, F. A critical validation of the value added intellectual coefficient: Use in empirical research and comparison with alternative measures of intellectual capital. J. Manag. Gov. 2020, 24, 1115-1145. [CrossRef]

20. Kowalska, M.K. Intellectual Capital: ISVA, the Alternative Way of Calculating Creating Value in Agricultural Entities-Case of Poland. Sustainability 2020, 12, 2645. [CrossRef]

21. Scafarto, V.; Ricci, F.; Scafarto, F. Intellectual capital and firm performance in the global agribusiness industry: The moderating role of human capital. J. Intellect. Cap. 2016, 17, 530-552. [CrossRef]

22. Cavicchi, C.; Vagnoni, E. Intellectual Capital in Support of Farm Businesses' Strategic Management: A Case Study. J. Intellect. Cap. 2018, 19, 692-711. [CrossRef]

23. Shakina, E.; Barajas, A.; Molodchik, M. Bridging the gap in competitiveness of Russian companies with intangible bricks. Meas. Bus. Excell. 2017, 21, 86-100. [CrossRef]

24. Yound, M.; Subramaniam, M.; Snell, S. Intellectual capital profiles: An examination of investments and returns. J. Manag. Stud. 2004, 41, 335-361. [CrossRef]

25. Roose, G.; Pike, S.; Fernstro, L. Managing Intellectual Capital in Practice; Elsevier: New York, NY, USA, 2005.

26. Brennan, N.; Connell, B. Intellectual capital: Current issues and policy implications. J. Intellect. Cap. 2000, 1, 206-240. [CrossRef]

27. Harrison, S.; Sullivan, P. Profiting from intellectual capital—Learning from leading companies. J. Intellect. Cap. 2000, 1, 33-46. [CrossRef]

28. Hudson, W. Intellectual Capital: How to Build, It, Enhance It, Use It; John Wiley \& Sons: New York, NY, USA, 1993.

29. Bontis, N. Assessing knowledge assets: A review of the models used to measure intellectual capital. Int. J. Manag. Rev. 2001, 3, 41-60. [CrossRef]

30. Nazari, J.A.; Herremans, I.M. Extended VAIC model: Measuring intellectual capital components. J. Intellect. Cap. 2007, 8, 595-609. [CrossRef]

31. Edvinsson, L.; Malone, S.M. Intellectual Capital: Realizing Your Company's True Value by Finding Its Hidden Brainpower; Harper Business: New York, NY, USA, 1997.

32. Medina, C.C.; Cabrales, A.L.; Cabrera, R.V. Leveraging the innovative performance of human capital through HRM and social capital in Spanish firms. Int. J. Hum. Resour. Manag. 2011, 22, 807-828. [CrossRef]

33. Mouritsen, J. Classification, measurement and the ontology of intellectual capital entities. J. Hum. Resour. Costing Account. 2009, 13, 154-162. [CrossRef]

34. Kooistra, J.V.d.M.; Zijlstra, S.M. Reporting on intellectual capital. Account. Audit. Account. J. 2001, 14, 456-476. [CrossRef]

35. Penman, S.H. Accounting for Intangible Assets: There is Also an Income Statement. Abacus 2009, 45, 358-371. [CrossRef] 
36. Pulic, A. Intellectual capital-Does it create of destroy value? Meas. Bus. Excell. 2004, 8, 62-68. [CrossRef]

37. Clarke, M.; Seng, D.; Whiting, R.H. Intellectual capital and firm performance in Australia. J. Intellect. Cap. 2011, 12, 505-530. [CrossRef]

38. Firer, S.; Williams, S.M. Intellectual capital and traditional measures of corporate performance. J. Intellect. Cap. 2003, 4, 348-360. [CrossRef]

39. Pulic, A. VAIC-An accounting tool for IC management. Int. J. Technol. Manag. 2000, 20, 702-714. [CrossRef]

40. Chang, W.S.; Hsieh, J.J. Intellectual capital and value creation is innovation capital a missing link? Int. J. Bus. Manag. 2011, 6, 3-12. [CrossRef]

41. Anifowose, M.; Rashid, H.A.; Annuar, H.; Ibrahim, H. Intellectual capital efficiency and corporate book value: Evidence from Nigerian economy. J. Intellect. Cap. 2018, 19, 644-668. [CrossRef]

42. Shakina, E.; Barajas, A. Value creation through intellectual capital in developed European markets. J. Econ. Stud. 2014, 41, 272-291. [CrossRef]

43. Pal, K.; Soriya, S. IC performance of Indian pharmaceutical and textile industry. J. Intellect. Cap. 2012, 13, 120-137. [CrossRef]

44. Fama, E.F.; French, K.R. A five-factor asset pricing model. J. Financ. Econ. 2015, 116, 1-22. [CrossRef]

45. Marx, R.N. The other side of value: The gross profitability premium. J. Financ. Econ. 2013, 108, 1-28. [CrossRef]

46. Molodchik, M.; Jardon, C.F.; Barajas, A. Intangible-driven performance: Company size matters. Int. J. Knowl. Based Dev. 2016, 7, 225-239. [CrossRef]

47. Arellano, M.; Bond, S. Some tests of specification for panel data: Monte Carlo evidence and an application to employment equations. Rev. Econ. Stud. 1991, 58, 277-297. [CrossRef]

48. Blundell, R.; Bond, S. GMM estimation with persistent panel data: An application to production functions. Econom. Rev. 2000, 19,321-340. [CrossRef]

49. Roodman, D. How to do xtabond2: An introduction to difference and system GMM in Stata. Stata J. 2008, 9, 86-136. [CrossRef]

50. Arellano, M.; Bover, O. Another look at the instrumental variable estimation of error-components models. J. Econom. 1995, 68, 29-51. [CrossRef]

51. Schultz, E.L.; Tan, D.T.; Walsh, K.D. Endogeneity and the corporate governance-performance relation. Aust. J. Manag. 2010, 35, 145-163. [CrossRef]

52. Xu, X.L.; Chen, H.H.; Zhang, R.R. The Impact of Intellectual Capital Efficiency on Corporate Sustainable Growth-Evidence from Smart Agriculture in China. Agriculture 2020, 10, 199. [CrossRef] 